\title{
ӨPPD

\section{Teacher's Use of WhatsApp Application to Solve Elementary School Students' Online Learning Difficulties}

\author{
Eko Kuntarto*, Faizal Chan, \& Nurul Qalbi Eka Pratiwi \\ Universitas Jambi, Jambi, Indonesia \\ *Email: nurulqalbiekapratiwi.pgsd@gmail.com
}

Submitted: 2021-04-21

DOI: $10.23917 / p p d . v 8 i 2.14210$

Accepted: 2021-12-27

Published: 2021-12-30

\begin{tabular}{ll}
\hline \multicolumn{1}{c}{ Keywords: } & Abstract \\
\hline Whatsapp; & This research aimed to describe the types of difficulties encountered by students \\
learning & when conducting online learning through WhatsApp, as well as how teachers \\
difficulties; & address students' learning difficulties. The method used in this research was \\
qualitative research method using case study design. Data were gathered \\
through online observation and interviews. Data analysis was carried out by \\
collecting data, analyzing data, and drawing conclusions. To check the validity \\
of the data, sources and technique triangulations were used. The results of this \\
research showed that there were several difficulties experienced by the students \\
during online learning through WhatsApp group, such as lack of support \\
facilities because students did not have their own mobile phones, unstable \\
internet network, and insufficient internet quota. Regarding the use of \\
WhatsApp in learning activities, students had difficulty discussing in the group \\
or using WhatsApp features. The teacher overcame the obstacles for students \\
who did not have their own mobile phones by asking their classmates or \\
neighbors wholived nearby to provide information related to learning activities. \\
To address challenges such as an unstable internet network, the teacher \\
instructed students to find a location with a good network while learning. Then, \\
regarding students who did not have an internet quota, the teacher recorded \\
the student's WhatsApp numbers so they could get free internet assistance from \\
the Ministry of Education and Culture. To solve problems related to the difficulty \\
of students discussing in groups and difficulties using the WhatsApp feature, the \\
teacher always guided and assisted students on how to use the WhatsApp \\
features in the learning process.
\end{tabular}

(C) The Author(s). 2021

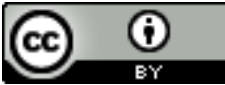

This work is licensed under a Creative Commons Attribution 4.0 International License 


\section{INTRODUCTION \\ Background}

According to the Minister of Education and Culture Regulation Number 81A Year 2013, learning is a method for students to master what is taught. Learning activity, in general, is an educational process that allows students to develop their potential and abilities, as well as the attitudes, knowledge, and skills required to live and socialize as a nation and contribute to human welfare.

The world is currently experiencing the COVID -19 pandemic, which has claimed many lives and represented a massive challenge for Indonesia and the rest of the world. The COVID-19 outbreak causes an impact on education as well. Based on Circular Letter No 3 Year 2020, in the context of preventing the development and spread of coronavirus disease (COVID -19), education units are directed to focus on several issues concerning the prevention and the transmission of coronavirus disease. Following the policies issued by the Minister of Education and Culture, namely Circular Letter Number 4 Year 2020 regarding the implementation of education during the coronavirus disease emergency, there are some changes in the learning process, in which teaching and learning activities are conducted remotely (from home) or online.

\section{Problem of Study}

This necessitates a shift in the learning process from face-to-face (offline) to online learning. A social media platform is a type of media where users can find information, communicate with one another, and make new friends online. As is well known, there are various types of social media, such as Facebook, Twitter, Line, BBM, WhatsApp, Instagram, Path, LinkedIn, Snapchat, and others (Trisnani, 2017). WhatsApp is one type of online social media platform that is simple to use and operate for students. WhatsApp, as a social media platform, enables its users to deliver specific announcements, various ideas, and learning resources, as well as to support online discussions (Amry, 2014). There are several advantages to using Whatsapp Messenger Group for learning: 1) It can easily be downloaded and free, 2) It allows the transmission of comments, writings, images, videos, sounds, and documents. 3) It can be used as a medium for publishing works or disseminating information. 4) It has a variety of features for disseminating information and knowledge, and 5) It makes online learning more convenient (Indaryani \& Suliworo, 2018).

Teachers must be creative in using WhatsApp, including the use of application features for delivering material, appointing assignments, collecting assignments, and conducting online learning assessments in order to produce effective learning outcomes. This needs to be a teacher's attention so that students do not have difficulty to participate in online learning. Learning difficulties occur when a person's learning process is disrupted by the emergence of conflicting responses or a person's inability to learn (Mulyadi, 2010). So, if there are problems or learning difficulties encountered by the students during online learning, teachers must be able to address the issues in various ways.

The teacher's role is critical in effectively utilizing WhatsApp in the learning process so that students do not find it difficult to participate in learning activities. Teachers can use WhatsApp to give assignments, interact with students, and collect assignments in order to prevent gatherings during the current pandemic and prevent the spread of COVID-19. Furthermore, the teacher's role is vital in providing solutions or ways to overcome learning difficulties experienced by students during the learning process. The researchers selected SD N 160/IX Simpang Tuan as the subject of the research. According to the results of the observations and interviews with the homeroom teacher, there were still some students at the school, particularly the fifth-grade students, who had difficulty participating in online learning using WhatsApp. 


\section{State of The Art}

Several studies have been conducted to investigate the use of WhatsApp in online learning. First, Alaby (2020) carried out research on the use of WhatsApp as a medium of information and learning. This study found that WhatsApp plays an important role in the lecture process. It is also used to improve the method of sending assignments. Second, Shodiq and Zainiyati (2020) discovered that using WhatsApp as a learning tool in the midst of the COVID-19 pandemic is very appropriate because this application is simpler, easier to use, and has more features than another online application. Third, research by Afnibar and Fajhriani (2020) revealed that students generally use WhatsApp to communicate and learn. WhatsApp also makes communication easier, supports learning activities, and assists students in learning activities. Fourth, Dewi's (2020) study discovered that using WhatsApp helps reduce the impact of COVID-19 on the implementation of online learning in elementary schools.

\section{Gap Study \& Objective}

COVID-19 has had such a large impact on education as it can be seen on the shifting of face-to-face learning into online learning through the use of different applications such as WhatsApp, Zoom, Google Classrooms, and others. This online learning can be quite effective if teachers, students, and parents work together. Fifth, a study by Wiguna et al. (2020), informed that the use of WhatsApp is a factor that significantly influences the learning process when it is conducted online. In this case, students in elementary school face a number of challenges when participating in the online learning process via WhatsApp application. Based on this context, the purpose of this research is to describe the students' difficulties in online learning using WhatsApp application, as well as the methods that teachers have used to help these students overcome their learning difficulties.

\section{METHOD}

Type \& Design

This is qualitative research using a case study design. The research was conducted at SD Negeri 160/IX Simpang Tuan, particularly in the fifth grade. This research was carried out during the even semester of the 2020/2021 academic year.

\section{Data \& Data Source}

The data were qualitative in the form of words gathered through observations and interviews. The participants of this research were fifth-grade students and the homeroom teacher. The first set of data focused on students' difficulties with online learning. These data were gathered from four students who struggled with online learning. The second set of data came from the fifth-grade students' homeroom teacher, and it was about how the teacher overcame students' difficulties. The data for this research were collected through observation and interviews.

\section{Data Collection Technique}

The observation technique was used to determine how the teacher used the WhatsApp social media platform to help students overcome learning difficulties. The researchers joined the WhatsApp group of the class, did the observations, and paid attention to the teacher and students' activities during the online teaching and learning process. The observations were done based on the observation guide. 
Table 1. Observation Guide

\begin{tabular}{|c|c|c|}
\hline No & Aspects observed & Indicator \\
\hline 1 & $\begin{array}{l}\text { Supporting facilities in } \\
\text { the form of WhatsApp } \\
\text { application }\end{array}$ & $\begin{array}{l}\text { 1. Have a mobile phone } \\
\text { 2. Have joined the WhatsApp group } \\
\text { 3. Have a stable internet connection } \\
\text { 4. Have an internet quota }\end{array}$ \\
\hline 2 & $\begin{array}{l}\text { The use of the } \\
\text { WhatsApp application }\end{array}$ & $\begin{array}{l}\text { 1. WhatsApp group is used to facilitate } \\
\text { discussion during the online learning } \\
\text { process. } \\
\text { 2. The class in WhatsApp group is used to } \\
\text { deliver information about learning } \\
\text { activities. } \\
\text { 3. All students actively participate in } \\
\text { discussion activities through WhatsApp } \\
\text { group chats. } \\
\text { 4. WhatsApp is active during the teaching } \\
\text { and learning process. } \\
\text { 5. WhatsApp is used every day. } \\
\text { 6. WhatsApp features are used in the } \\
\text { online learning process. } \\
\text { 7. There are obstacles in using WhatsApp } \\
\text { for online learning. } \\
\text { 8. The teacher provides a solution when } \\
\text { students encounter a problem during } \\
\text { the learning process. }\end{array}$ \\
\hline
\end{tabular}

The researchers also employed semi-structured interviews. Data collection from interviews began by preparing an interview guide sheet. Interviews were conducted with the homeroom teacher and the fifth-grade students who had difficulty following online learning by complying with health protocols by wearing masks, washing hands, and using hand sanitizers. During the interview, the teacher and students were asked to respond to questions based on the actual situation.

Table 2. Interview Guide

\begin{tabular}{|c|c|c|}
\hline $\begin{array}{c}\text { Data } \\
\text { Sources }\end{array}$ & $\begin{array}{l}\text { Aspects } \\
\text { observed }\end{array}$ & Indicator \\
\hline \multirow[t]{8}{*}{ Teacher } & Supporting & 1. Have a mobile phone \\
\hline & facilities in & 2. Have WhatsApp application on the phone \\
\hline & the form of & 3. Have a stable internet connection \\
\hline & $\begin{array}{l}\text { WhatsApp } \\
\text { application }\end{array}$ & 4. Have an internet quota \\
\hline & The use of & 1. Have joined the class WhatsApp group \\
\hline & $\begin{array}{l}\text { WhatsApp } \\
\text { application }\end{array}$ & $\begin{array}{l}\text { 2. WhatsApp group is used to facilitate } \\
\text { students with discussions. }\end{array}$ \\
\hline & & $\begin{array}{l}\text { 3. WhatsApp group is used to notify students } \\
\text { about upcoming learning activities. }\end{array}$ \\
\hline & & $\begin{array}{l}\text { 4. WhatsApp is active during the teaching and } \\
\text { learning process. }\end{array}$ \\
\hline
\end{tabular}




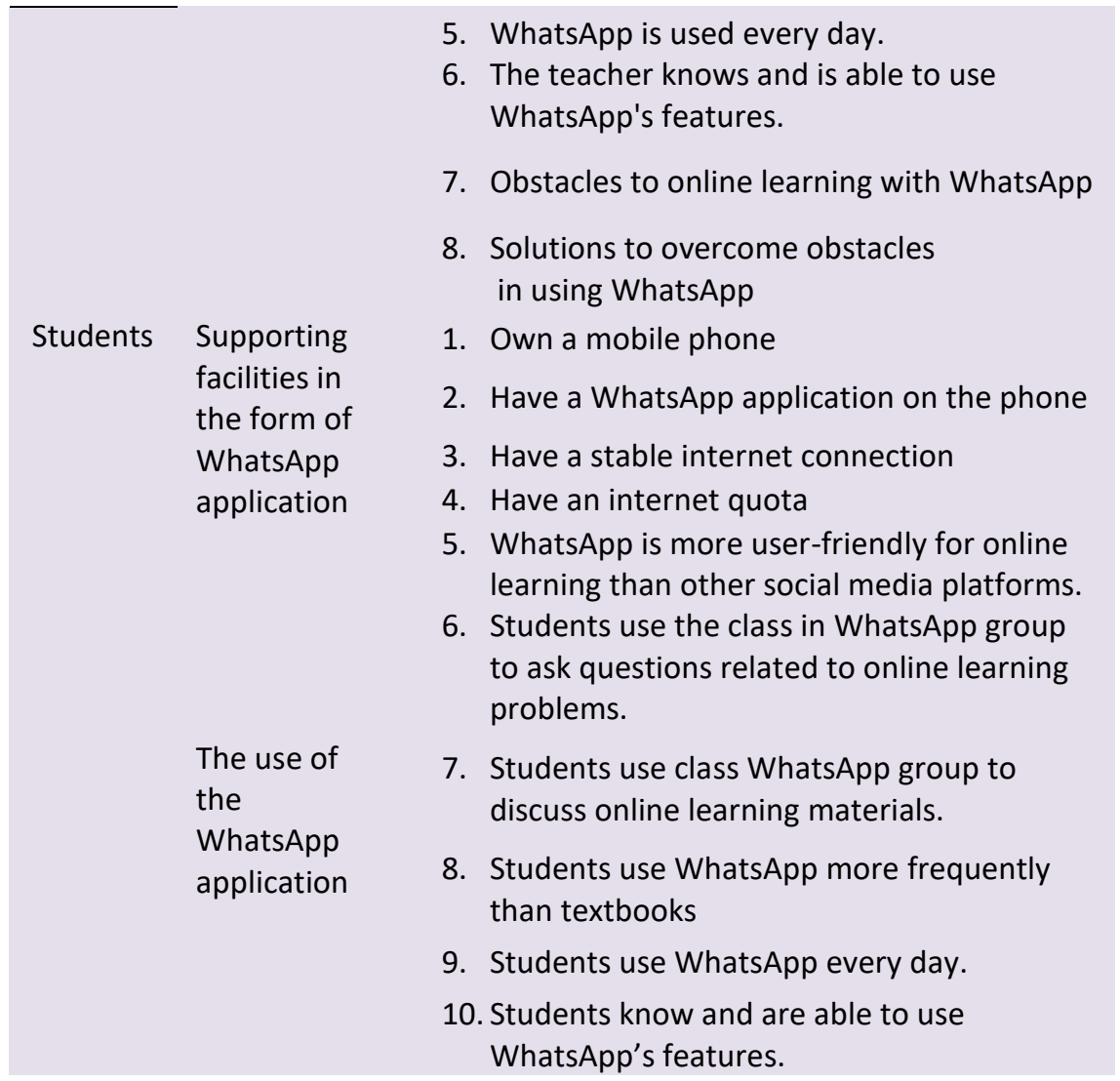

\section{Data Analysis}

Several triangulation techniques were employed in this research. First, source triangulation was used to test the validity of the data by cross-referencing the data from various sources. Second, technique triangulation was used to test the validity of the data by comparing it to the same source but using different techniques. The data analysis technique was carried out continuously until it was completed, causing the data to become saturated. The stages in data analysis include data collection, data analysis, and conclusion drawing.

\section{RESULTS}

This research aims to describe the students' difficulties in learning online using the WhatsApp application, as well as the methods that teachers have used to help these students overcome their learning difficulties. Data were gathered through observations conducted during the research period through the WhatsApp group. In addition, to enrich the data, interviews with the participants were also conducted. The followings are the findings from interviews with the teacher and fifth-grade students at SD Negeri 160/IX Simpang Tuan who had difficulty in learning online using WhatsApp.

\section{Forms of Students' Online Learning Difficulties Using WhatsApp}

According to the research findings, the form of students' difficulties in online learning using WhatsApp was related to supporting facilities such as the WhatsApp application. It was found that the students did not own mobile phones, that the internet network was unstable, and that they did not have an internet quota. Then, the difficulties associated 
with the use of the WhatsApp platform were that students did not understand how to use WhatsApp features, so they did not dare to ask questions in the group, and they became inactive in the WhatsApp group during learning. Further explanation is given below.

The researchers discovered several findings regarding the students' difficulties with online learning using WhatsApp. The findings of the observations and interviews revealed that the difficulties of the fifth-grade students were related to a lack of supporting facilities, in this case, the WhatsApp application. The following is a discussion of the problems encountered by students at SD Negeri 160/IX Simpang Tuan when using WhatsApp for online learning.

1. Students did not have their own mobile phones

One of the reasons students struggled with assignments was that they did not have their own mobile phones. In this case, they used their parents' mobile phones. As a result, when the teacher distributed assignments and learning materials, students were unable to join the WhatsApp group. They finished the assignments when their parents returned home from work. Under these conditions, learning did not run effectively.

It was mentioned by RJ, one of the fifth-graders at Sekolah Dasar Negeri 160/IX Simpang Tuan:

"I don't have my own mobile phone; the one I use belongs to my father; as a result, I can't complete my assignments on time when the teacher posts them in the WhatsApp group. I didn't do it immediately. I'm going to have to wait for my father to get home from work. Then I'll check the group and finish my homework" (23/01/2021).

\section{Unstable internet connection}

Another issue was the limited internet network at the student's house due to its location in the garden. This resulted in students not receiving messages from the teacher in the WhatsApp group, which could impede the teaching and learning process in online learning.

As explained by student $A$ in our interview:

"I frequently missed lessons because the signal in my house was lost, and also, since my house is in the garden, it is difficult to find a good internet connection. Sometimes, I have to leave my house or go to a friend's house outside the garden to find an internet connection" (30/01/2021).

3. Students do not have an internet quota

Another challenge in online learning is the Internet quota or data limit. The difficulty discovered in this research was that students did not have an internet quota. The internet quota that students used was purchased independently. They did not receive free internet quota assistance from the Ministry of Education and Culture. Students were unable to purchase their quota at any time. Due to their parent's financial situation, students must first postpone the purchase of their internet quota. As a result, students missed out on online learning, which was done through a WhatsApp group.

This is supported by the results of interviews with a fifth-grade student of SD N 160/IX Simpang Tuan, initials AP:

"In terms of assignments, I have difficulty accepting assignments from teachers who send them through the WhatsApp group because my brother and I share one mobile phone. When I want to do an assignment, my brother's internet quota runs out, so I can't check the assignments assigned by the teacher" (20/01/2021). 
According to the findings of observations and interviews, the online learning difficulties encountered by students when studying using WhatsApp during the COVID-19 pandemic are students' lack of personal mobile phones, unstable internet connections, and limited internet quotas. Due to these difficulties, students are unable to follow the teacher's lessons. Learning through WhatsApp groups is one option for students to continue learning during the COVID-19 pandemic in order to prevent the virus's spread and transmission.

- The Use of WhatsApp

During the research, the researchers found that students encountered problems in online learning.

Based on the findings of observations and interviews, the difficulties of learning faced by fifth-grade students at SD Negeri 160/IX Simpang Tuan are as follows:

1. Students find it difficult to engage in a discussion in a WhatsApp group.

During online learning using WhatsApp, some students still had difficulty discussing the tasks assigned by the teacher through the WhatsApp group because the mobile phone belonged to their parents, as a result, students could not use WhatsApp during school hours. Students also did not dare to ask the teacher who assigned the tasks if they were confused about how to complete the assignment.

It is in accordance with the results of the interview with one of the respondents, initials MA:

"When the teacher sends assignments to the group, I sometimes didn't understand the tasks. Furthermore, the WhatsApp account I use belongs to my parents, so I won't be able to participate in the lessons during school hours. I didn't even dare to ask questions in the WhatsApp group. When I didn't understand, I asked a friend via WhatsApp chat, and he sent me a video of how he completed the task" (06/02/2021).

\section{Students find it difficult in using WhatsApp's features}

The issue discovered was that students had difficulty using the WhatsApp feature, such as students could not download learning materials or send photos of their assignments to the teacher due to memory limitations, and students failed to play videos sent by the teacher. When the WhatsApp memory is full, the phone will undoubtedly become slow and WhatsApp will cease to function properly.

It was uttered by TA, a fifth-grade student at Sekolah Dasar Negeri 160/IX Simpang Tuan:

"When the teacher started the lesson in the group and sent photos and learning videos, I couldn't download them because WhatsApp warned me that my WhatsApp memory was full, so I couldn't see what assignment announcements the teacher made. If we receive a notification that our WhatsApp memory is full, our phones will no longer receive message notifications or WhatsApp chat" (06/02/2021)

- Teacher's Strategy to Overcome Students' Difficulty in Online Learning Through WhatsApp

From the research findings, students' difficulties were related to learning support facilities, such as students' lack of personal mobile phones. The teacher provided a solution in which classmates or neighbors shared information about the lessons taught that day, and they could discuss it together through a WhatsApp group on their friend's mobile phone. The teacher also allowed students to submit their assignments when their parents came home from work. 
This information was conveyed by $A Z$, one of the participants of this research:

"As students do not have their own mobile phones but rather those of their parents or siblings, I sent messages via WhatsApp chat to friends or neighbors who are close to them so they can share the assignments I give on that day. I also allow the students to send their assignments late because the most important thing is that they want to complete the tasks. Personally, students' effort to finish their tasks is enough to make me grateful" (30/01/2021)

To overcome online learning difficulties caused by limited internet quotas and unstable internet signals in the area of residence, teachers provided a solution by registering student phone numbers with school operators, to be registered as the recipient of free internet quota assistance from the Ministry of Education and Culture, so that students can carry out learning without any obstacles.

This information was conveyed by the homeroom teacher of the fifth-grade students of SD Negeri 160/IX Simpang Tuan, initials AZ:

"If a student is having trouble with internet quotas, I report it to the school operator so that the mobile phone number registered as a recipient of free quota assistance from the Ministry of Education and Culture, allowing students to participate in learning and do assignments without interruption. Similarly, if an internet signal is unstable, I advise students to find a location with a good network during learning hours"(30/01/2021)

The teacher managed the online learning process through WhatsApp by assigning tasks to the students. The teacher gave assignments once a day to prevent students from becoming lazy and having difficulty or confusion with multiple assignments. The teacher also provided clear instructions for the assignments and allowed students to ask and answer questions in the WhatsApp group or private chats, as well as through WhatsApp calls.

As mentioned by $A Z$, the homeroom teacher:

"When submitting assignments, I took advantage of existing WhatsApp features to overcome online learning difficulties experienced by students. I sent a downloaded video about material that the students did not understand. Besides, I also provided students the opportunity to ask questions either in groups or through private chats. I shared sample photos of assignments that they did not understand, and in addition to using chat, I sent voice notes to explain the learning materials" (30/01/2021)

Then, it was also found that the teacher's method of dealing with students who had learning difficulties during online learning was that the teacher provided learning media using WhatsApp by sending learning videos to the group and providing an explanation of the learning material that was sent to the group. The teacher also offered a discussion session in the WhatsApp group so that students could ask questions to the teacher regarding learning material that has not been understood.

\section{DISCUSSION}

Based on the findings of this current research, several points regarding students' difficulties in online learning through WhatsApp group as well as teacher's strategies in addressing students' problems are discussed below. 
During this research (18 January 2021-18 February 2021), online learning was carried out using WhatsApp. Teachers and students conducted teaching and learning activities in a WhatsApp group. During this Covid-19 pandemic, the teacher played an important role in online learning. Teachers guided and assisted students in overcoming online learning difficulties by sending learning materials and explaining tasks that students must complete while studying at home. Then, when students experienced learning difficulties, the teacher offered solutions so that students could continue to learn and did not miss out on the learning material.

In this case, the teacher followed a policy issued by the Minister of Education and Culture, Nadiem Anwar Makarim, who issued Circular Letter Number 3 Year 2020 through the letter Number 36962/MPK.A/HK/2020 concerning online Learning to prevent the spread of Corona Virus Diseases (COVID-19). This policy has compelled teachers and students to continue their learning at home through the use of distance learning media, one of which is the WhatsApp application, which was used by the fifth-grade teacher at SD Negeri 160/IX Simpang Tuan.

During the pandemic, learning was done online through WhatsApp. The teacher distributed assignments, and students were expected to complete them. However, some students were still late in submitting their assignments. This occurred as a result of some difficulties or obstacles encountered during online learning. The difficulty encountered was that students did not have their own mobile phones, but rather those of their parents or siblings. So, in order to complete school assignments, students had to wait for their parents to return home; in some cases, students submitted assignments at night when their parents were at home.

According to Indaryani and Suliworo, "Whatsapp is a messaging-based application for smartphones, with a basic interface similar to Blackberry Messenger" (Indaryani \& Suliworo, 2018). As a result, smartphones are essential for using the WhatsApp application. When students did not have their own mobile phones, the teacher overcame online learning difficulties by sending private chats to students' parents, so that they left their mobile phones at home for their children to study, or by sending messages to classmates who were close to their homes. Suryani, (2017) argued, "the WhatsApp application also has a message status in the form of a sign that functions to find out the status of the message, so that teachers can monitor students whether they have opened the messages, read, or not at all". With the message's status, the teacher can more easily track which students have done the assigned tasks.

In online learning through the WhatsApp group, the assignments were distributed every day during class hours. Following the distribution of the assignment by the teacher, the student must submit the assignment via WhatsApp, and they must also send a photo of proof when they were working on the assignment, along with a photo of the completed task. However, some students did not know the task assigned by the teacher during class and did not complete it.

From the data, this happened due to students running out of their internet quota, preventing them from receiving messages from the teacher in the WhatsApp group. Hartono (2012) argued, "WhatsApp is a cross-platform messaging application that allows users to exchange messages without using SMS fees because WhatsApp uses the same internet network data package for email, web browsing, and others". Conforming to this explanation, the teacher's method of overcoming this problem was to register the students' mobile phone numbers with school operators so that they were recorded as recipients of free internet quota assistance from the Ministry of Education and Culture. 
As stated in research data, one of the learning difficulties during online learning using WhatsApp was an unstable internet signal, which prevented students from sending assignments to the teacher on time. This is consistent with Nasrullah's (2015) opinion that "social media has a special character, namely the network, the infrastructure that connects computers with other hardware. Computers or mobile phones must be connected through a connection in order to communicate with other users." Purwanto et al. (2020) confirmed this by stating that "internet communication costs money". The factor causing difficulties in online learning is a less stable internet network because not all residences are covered by internet service. According to Indaryani and Suliworo (2018), "WhatsApp also uses 3G/4G or WiFi connections for data communication". Parents' limited abilities in using smartphones and internet fees, as well as other factors, have become obstacles in the learning process, resulting in online learning difficulties during the covid-19 pandemic. To overcome students who have difficulty in online learning, the teacher provided a solution by calling them directly using WhatsApp calls and instructing them to move to places where there is a good signal during learning hours or online discussions.

During the covid-19 pandemic, the teacher sent learning assignments every day, with one task per day. Although there was only one task, there were students who had difficulty understanding the material presented by the teacher, and as a result, students were lazy to complete the task. This is consistent with Dalyono's (2009) belief that "learning difficulties or learning disorders are situations in which a person's learning process is hampered due to the emergence of conflicting responses." It also refers to a person's inability to learn." Faced with these issues, the teacher attempted to use the features of the WhatsApp social media platform to provide learning videos that could be downloaded and sent to the class in WhatsApp group, and the teacher also shared photos of examples of how to finish the assignments.

According to Indaryani and Suliworo (2018), "there are several benefits of using Whatsapp Messenger Group in learning: 1) It is easily and freely obtained, 2) it allows the transmission of comments, writings, images, videos, sounds, and documents, 3) it can be used to publish works or disseminate information, 4) it has various features for disseminating information and knowledge, and 5) it facilitates online learning. With the current pandemic, teachers must be able to use WhatsApp features in the learning process to overcome online learning difficulties and to create meaningful learning for students.

Based on the discussion above, WhatsApp can provide benefits and serve as a solution to learning difficulties faced by students. By maximizing the use of WhatsApp for learning, students do not miss the material presented by the teacher. The use of this application also makes it easier for students to succeed in their learning when face-to-face learning is not possible. By using WhatsApp, students can still carry out learning, although it is not as effective as face-to-face learning.

\section{CONCLUSION}

The objective of this research is to describe the different types of online learning difficulties that students face when using WhatsApp, as well as how teachers can help students overcome these difficulties. Based on the result of the research and the discussion that has been presented, it is possible to conclude that the types of learning difficulties experienced by students are related to students' lack of support facilities because students did not have their own mobile phones, unstable network, and internet quota. Then, when it comes to WhatsApp features, students had trouble discussing in WhatsApp groups and using WhatsApp features. The teacher overcame the obstacles for students who did not have their own mobile phones by asking their classmates or neighbors who lived nearby to 
provide information related to learning activities. To address challenges such as an unstable internet network, the teacher instructed students to find a location with a good network while learning. Then, regarding students who did not have an internet quota, the teacher recorded the student's WhatsApp numbers so they could get free internet assistance from the Ministry of Education and Culture. To solve problems related to the difficulty of students discussing in groups and difficulties using the WhatsApp feature, the teacher always guided and taught students on how to use the WhatsApp features in the learning process.

The findings of this research are expected to provide information and increase teacher understanding of how to use WhatsApp to help elementary school students overcome online learning difficulties during the COVID-19 pandemic. Furthermore, the results of this research can also be used to guide teachers in selecting effective media during the COVID19 pandemic. For researchers, as prospective teachers, the results of this study increase researchers' understanding that teachers must have their own method or solution in overcoming students' difficulties in online learning using WhatsApp.

\section{REFERENCES}

Afnibar dan Fajhriani. (2020). Pemanfaatan WhatsApp Sebagai MediaKomunikasi Antara Dosen Dan Mahasiswa Dalam Menunjang KegiatanBelajar (Studi Terhadap Mahasiswa Uin Imam Bonjol Padang. JurnalKomunikasi dan Penyiaran Islam.Vol.11(1).70-83.

Ahmadi, Rulam. 2016. Metodelogi Penelitian Kualitatif. Yogjakarta: Ar-Ruzz Media

Alaby, M. A. (2020). Media Sosial Whatsapp Sebagai Media Pembelajaran Jarak Jauh Mata Kuliah Ilmu Sosial Budaya Dasar (ISBD). Ganaya: Jurnal IImu Sosial Dan Humaniora, 3(2), 273-289.

Amry, A. B. (2014). The impact of WhatApp mobile social learning on the achievement and attitudes of female students compared with face to face learning in the classroom. European Scientific Journal, 10(22), 116-136.

Dewi, W. A. F. (2020). Dampak COVID-19 terhadap Implementasi Pembelajaran Daring di Sekolah Dasar. Edukatif : Jurnal Ilmu Pendidikan, 2(1), 55-61.

Hartono. (2012). PAIKEM Pembelajaran Aktif, Inovatif, Kreatif, Efektif, dan Menyenangkan. Pekanbaru : Zanaf.

Indaryani, E., \& Suliworo, D. (2018). Dampak Pemanfaatan WhatsApp Dalam Meningkatkan Motivasi Belajar Siswa Pada Pelajaran Fisika. Prosiding Seminar Nasional Quantum, 25, 25-31.

Kamila, H. P., (2019). Pengaruh Pemanfaatan Media Sosial Whatsapp TerhadapMotivasi Belajar Bahasa Indonesia Di Smp Islam Al Wahab Jakarta Tahun Pelajaran 2018/2019. (Skripsi Mahasiswa Ilmu Tarbiyah Dan Keguruan Uin Syarif Hidayatullah)

KBBI. (2016). Kamus Besar Bahasa Indonesia. (KBBI). [online].

Mulyadi. (2010). Diagnosis Kesulitan Belaja dan Bimbingan Terhadap Kesulitan Belajar Khusus.

Narti, S. (2017). Pemanfaatan "Whatsapp" Sebagai MediaKomunikasi Dosen Dengan Mahasiswa Bimbingan Skripsi(Studi Analisis Deskriptif Pada Mahasiswa IImu Komunikasi BimbinganSkripsi Universitas Dehasen Bengkulu Tahun 2016). 
JurnalProfessional, 4(1).

Purwanto, A., Pramono, R., Asbari, M., Santoso, P. B., Wijayanti, L. M., Choi, C. H., \& Putri, R. S. (2020). Studi Eksploratif Dampak Pandemi COVID-19 Terhadap Proses Pembelajaran Online di Sekolah Dasar. EduPsyCouns: Journal of Education, Psychoslogy and Counseling, 2(1), 1-12.

Sadikin, A., \& Hamidah, A. (2020). Pembelajaran Daring Di Tengah WabahCovid-19(Online Learning In The Middle of The Covid-19Pandemic.Jurnalllmiah Pendidikan Biologi.Vol.6(2). 214-224

Shodiq, I. J., \& Zainiyati, H. S. (2020). Pemanfaatan Media Pembelajaran E-Learning Menggunakan Whastsapp Sebagai Solusi Ditengah Penyebaran Covid-19 Di Mi Nurulhuda Jelu. Al-Insyiroh: Jurnal Studi Keislaman, 6(2), 144-159.

Sugiyono. 2005. Metode Penelitian Bisnis. Bandung: Alfabeta

Suryani, R. (2017). Fungsi WhatsApp Grup Shalihah Cabang Bandar Lampung Sebagai Pengembangan Media Dakwah Dalam Menentukan Akhlakul Karimah.

Sahidillah, M.W., \& Miftahurrisqi, P. (2019). WhatsApp sebagai media literasi digital siswa. Jurnal varadika kajian penelitian pendidikan, 31(1),52-57.

https://journals.ums.ac.id/index.php/varidika/issue/view/850

Trisnani. (2017). Pemanfaatan WhatsApp sebagai Media Komunikasi danKepuasan Dalam PenyampaianPesan Dikalangan Tokoh Masyarakat.Jurnal Komunikasi, Media DanInformatika, 1-12.

Wiguna, R., Sutisnawati, A., \& Lyesmaya, D. (2020). Analisis Proses Pembelajaran Siswa Berbasis Onine di Kelas Rendah Pada Masa Pandemic conid-19. Jurnal Perseda, III(2), 7579. 